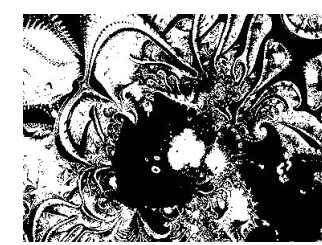

\title{
DIFFERENT MEASUREMENT APPROACHES AS SOURCES OF DIFFERENCES IN DATA ON THE PREVALENCE OF PEER VIOLENCE
}

Tena VELKI

Faculty of Teacher Education, Osijek

Gordana KUTEROVAC JAGODIĆ

Faculty of Humanities and Social Sciences, Zagreb

UDK: $303: 364.636$

$316.624 .3: 364.636$

Izvorni znanstveni rad

Primlieno: 21. 4. 2013.

Paper presented at the 4th Scientific Conference on the Issues of Violence: Violence and Mental Health - An Interdisciplinary Approach (Osijek, $29 / 11-1 / 12$ 2012)
The goal of this research was to investigate the difference in results of prevalence of peer violence when using different measurement approaches (definitional and behavioral) and different data collecting methods (self-rating, peer rating, peer nomination, self-nomination). The article presents results from two different researches on two samples of school-aged children from two towns in Slavonia. Prevalence of peer violence, in both samples, was measured by self-rating method based on behavioral approach. Pupils from the first sample gave self-ratings and peer ratings of peer violence prevalence, based on definitional approach. Pupils from the second sample gave peer nomination and self-nomination of peer violence based on definitional approach. The results have shown a higher prevalence of peer violence when using definitional approach and the results were the same regardless of using peer ratings or self-ratings. Self-ratings methods based on behavioral approach and peer nomination based on definitional approach have shown same peer violence prevalence but a slightly higher prevalence was obtained when using self-nomination. The study shows that it is necessary to use multimethod approach when testing the peer violence prevalence.

Keywords: prevalence, peer violence, behavioral approach, definitional approach, nomination, rating

Tena Velki, Faculty of Teacher Education, Cara Hadrijana 10, 31000 Osijek, Croatia.

E-mail: tena.velki@gmail.com 
Peer violence is defined as any form of physical or verbal behavior performed by a particular child or group of children over another child with the intent to inflict discomfort, pain, injury, or to cause fear (Farrington, 1993; Olweus, 1998). Researchers categorize children involved in peer violence according to their roles in violent events, and, therefore, they differentiate perpetrators of violence (children who only commit peer violence), passive victims (children who only experience peer violence), provocative victims (children who both perpetrate and experience peer violence) and uninvolved children (children who neither perpetrate nor experience peer violence) (Olweus, 1998).

Peer violence inflicted by children of the same or similar age, and especially bullying, which refers to repeated acts of violence of a more powerful child against the weaker one (Rajhvajn Bulat \& Ajduković, 2012), has devastating effects on different aspects of the child's functioning. Effects of bullying on physical health include headaches, insomnia, dizziness, chronic pain and many others (Due et al., 2005; Fekkes, Pijpers, \& Verloo-Vanhorick, 2004). Peer-to-peer violence has even more devastating effects on the child's mental health which include depression, anxiety, behavioral disorders, low self-esteem, negative self-image, etc. (Brunstein Kolmek et al., 2008; Kumpulainen, 2008). Also, bullying can have long-lasting negative effects on the psychological wellbeing in adults (Hugh-Jones \& Smith, 1999; Rigby, 2003) causing depression, low self-esteem, suicidal thoughts and suicidal attempts, etc. Because of all the aforementioned, peer violence is of great interest to the general public and professionals, who often express their worries because of the increasing prevalence. Information about the prevalence of these phenomena is important for those who take care of children so that they can take appropriate measures for its prevention as well as providing adequate assistance to victims and perpetrators of peer violence.

Statistics on the prevalence of peer violence in different countries vary from 9 to 32 percent for rates of victimization and from 3 to 27 percent for rates of perpetration of violence (Stassen Berger, 2007). The prevalence of peer violence is mostly investigated in the school context where the peer violence usually takes place. Having been bullied in school was reported by 19\% of pupils in England, 14\% in Norway, 17\% in Spain, $15 \%$ in Japan and 16\% in the U.S. (Olweus, 1998). Studies showed that the prevalence varies according to children's age (Cook, Williams, Guerra, Kim, \& Sadek, 2010b). Among children under the age of 11 there were $16 \%$ of perpetrators of violence, about $18 \%$ of victims and about $7 \%$ of provocative victims of peer violence. Prevalence was higher among older children and studies showed that among children between the ages 12 and 
DRUŠ. ISTRAŽ. ZAGREB GOD. 23 (2014), BR. 2 STR. 259-281

VELKI, T., KUTEROVAC JAGODIĆ, G. DIFFERENT..
14 there were about $20 \%$ of the perpetrators of violence, about $26 \%$ of the victims and about $10 \%$ of provocative victims. Studies of cyber violence, a new form of violence that includes posting or text messaging of harmful, insulting or threatening information and disinformation, showed somewhat lower prevalence that varied from $4.5 \%$ (fifth grade of primary school) to $12.9 \%$ of the perpetrators of violence (eighth grade of primary school) (Williams \& Guerra, 2007). Previous research in primary schools in Croatia showed that about $8 \%$ of children perpetrate violence, $19 \%$ of children are exclusively victims of peer violence and $8 \%$ of children are provocative victims (Buljan Flander, Ćorić Špoljarić, \& Durman Marijanović, 2007; Profaca, Puhovski, \& Luca Mrđen, 2006). More recent research of Sušac, Rimac, and Ajduković (2012) on a national sample of children, found the prevalence of $2.3 \%$ of perpetrators of violence, $14.4 \%$ of victims and $7.7 \%$ of provocative victims (fifth grade of primary school). Those numbers increased with age so those researchers found that in the seventh grade of primary school there were $6.5 \%$ of perpetrators of violence, $17.6 \%$ of victims and $16.4 \%$ of provocative victims.

It is assumed that the source of the large differences in data prevalence of peer violence may reflect real differences in the observed behavior, but it can also be the result of methodological differences between the studies. In fact, studies differ in the definition of peer violence, data collection methods, sources of data, the age of children who were assessed, their role in the peer violence, but also in many other factors such as time and circumstances of data collection, education policy, and even the moral values of the country where the data was collected (Stassen Berger, 2007). The purpose of this study was to compare the prevalence data on peer violence collected by the use of different research approaches, various methods of data collection, as well as different sources and instruments of data collection, all in order to contribute to the clarification of the possible sources of differences in the prevalence of peer-to-peer violent behavior among children. Therefore, a short review of approaches and methods of measurement in the field of peer violence follows, with an emphasis on those used in this study.

\section{Approaches and methods of research on peer violence}

Two approaches to assessment of peer violence are commonly used: the definitional approach and the behavior-based or behavioral descriptor approach (Swearer, Siebeckerm, Johnsen-Freriches, \& Wang, 2010). According to the definitional approach the definition of peer violence is presented to a child, and the child rates the frequency of doing the described behaviors (for themselves or the peers) or nominates the peers 
DRUŠ. ISTRAŽ. ZAGREB GOD. 23 (2014), BR. 2, STR. 259-28

VELKI, T., KUTEROVAC JAGODIĆ, G.: DIFFERENT... (sometimes including themselves) who behave as described by the definition. The main advantage of this approach is that a definition presented to children usually includes all theoretical criteria for bullying (imbalance of power, intent to inflict harm, and duration/repetition of behavior), and, therefore, helps children to understand how researchers define peer violence. The main disadvantage of this approach is that the definitions used are relatively long and complex, and, therefore, difficult for children to remember or to understand (especially younger children). In addition, these definitions are all inclusive, i.e. they usually include many different types of violent behavior, or different types of bullying, and that might be confusing for children because they do not know how to respond when peers do some of the violent behaviors given by the definition, but not all of them. Furthermore, the direct request to participants to identify themselves as victims or bullies can cause reluctance, avoidance to answer, as well as unpleasant emotional reactions. Finally, a comparison of studies, particularly cross-cultural comparison, is restricted due to the fact that many studies use different definitions of bullying/peer violence, or when they use the same definitions it is often not ensured that they have the same meaning in different cultures and languages.

The second measurement approach to peer violence is the behavioral descriptor approach in which descriptions of specific violent behaviors towards peers are presented (usually in the form of questions or statements) and the child is asked to rate the frequency of committing/suffering such behavior (for himself or herself or their peers). Sometimes instead of temporal answers only a binomial rate of occurrence of certain behavior (true/false or yes/no) is required. The main advantage of this approach is that the very term of bullying/ peer violence is not explicitly given as a term, or as a cluster of behavior and, therefore, the possibility of giving socially desirable responses is reduced. Also, simple and more concrete descriptions of behavior are clearer and easier to understand and, therefore, more straightforward to rate. Also, with this approach it is easier to explore different forms of peer violence. The main disadvantage of this approach is that the items that are rated do not necessarily meet all the criteria for the definition of bullying. That means that simple descriptions of behaviors do not include information about the context in which a particular behavior occurred, and often they do not include information about the child's intention to perpetrate violent behavior. Furthermore, this approach is too broad and quite complex when one rater (e.g. the teacher) is asked to evaluate different behaviors for more children (for example, all the pupils in the class). 
DRUŠ. ISTRAŽ. ZAGREB GOD. 23 (2014), BR. 2 STR. 259-281

VELKI, T., KUTEROVAC JAGODIĆ, G. DIFFERENT..
In addition to the different approaches to measurement of peer violence, studies on this issue also differ in data collection methods and sources of data, i.e. informants about peer violence. Various self-rating and peer rating methods are the most frequently used, but sociometric methods of peer nominations and self-nominations are also often applied. Other methods of study include, although less frequently, unstructured observation, structured observation, diaries, archival records, interviews, and various other sociometric procedures.

The most commonly used self-rating measures are questionnaires (for example, the most popular questionnaire is the Olweus Bully/Victim Questionnaire; Olweus, 1996) in which the child evaluates his or her own behavior. According to the results in these surveys, children are usually classified into several categories: as bullies/perpetrators, victims or passive victims, provocative victims and as uninvolved in the violence (Cornell \& Bandyopadhyay, 2010). Self-rating measures are cost-effective, and because the information is given by the very participants in peer violence, we can be sure that they will have the best knowledge of the situational factors as well as information on the participants' intention of perpetrating peer violence. According to the studies on prevalence of peer violence, this method gives the most reliable identification of bullies and victims, particularly if they are used anonymously (Olweus, 2010). However, certain studies suggest that these measures do not yield the most accurate data on peer violence (Perry, Kusel, \& Perry, 1988). The critics of this method state that the use of self-report instruments usually underestimates the actual prevalence because the bullies, with the aim of maintaining a socially desirable image of themselves, are reluctant to identify themselves as such, while the victims are prone to disclaim and deny their victimization (Pellegrini \& Bartini, 2000). Also, for many self-report instruments and questionnaires on peer violence, information about psychometric characteristics, particularly about the reliability and validity are missing.

Peers are often used as informants in studying peer violence. Sociometric procedures and measures that use peer ratings can be very simple and useful for younger children, but also very complex. When it comes to assessing younger children, they could be asked to select photos and pair them with the descriptions of certain violent behaviors. Older children may be asked to rate their peers on questionnaires covering different aspects of violent behaviors. Studies have shown that children are competent identifiers of bullies and victims in the classroom, and that the reliability of sociometric procedures and peer rating measures is satisfactory (Pakaslahti \& Keltikangas-Jarvinen, 2000). The main advantage of peer ratings is obtaining assessments from multiple informants, which 
DRUŠ. ISTRAŽ. ZAGREB GOD. 23 (2014), BR. 2, STR. 259-28

VELKI, T., KUTEROVAC JAGODIĆ, G.: DIFFERENT... reduces measurement errors. However, some researchers still claim that, when studying the prevalence of peer violence, it is best to use questionnaires in which descriptions of specific behaviors are offered, and the child determines a frequency and/or intensity of such behaviors or those behaviors in its peers (Colvin, Tobin, Beard, Hagan, \& Sprague, 1998; Olweus, 1998). The main disadvantage of rating a large number of peers by means of questionnaires is the demanding procedure. Namely, a pupil needs to make a large number of comparisons to evaluate one's behavior in the classroom, which can be a very complex process. Therefore, in their assessments, pupils often rely on the reputation of peers and other people's interpretations or on friendship, rather than on the actual behavior of a certain child. There is also the question of criteria for defining the categories of bullies, that is, peer nominations are needed for categorizing a pupil as a bully. Also, these methods are not anonymous, so the inevitable question is whether and how many pupils are actually honest in their evaluations (e.g., not wanting to "snitch on" others).

Depending on the methods used and the approach to the measurement of peer violence, the obtained statistics on the prevalence of peer violence are very different. Several meta-analytic studies (Cook, Williams, Guerra, \& Kim, 2010a; Knight, Guthrie, Page, \& Fabes, 2002) have shown that the prevalence of peer violence for bullies and victims is the lowest when the pupil is asked to nominate their peers, while it is equally high when self-ratings and peer ratings of the frequency of peer violence are used. The prevalence of peer violence is higher when the definitional approach is used as compared to the behavioral approach, while when the behavioral approach is used, there is a higher prevalence of victims and provocative victims. When using different methods, the prevalence of peer violence is equal when using self-ratings and peer nominations, especially when the public expression of violent behavior is assessed (Pellegrini \& Bartini, 2000).

\section{The degree of similarity in data on peer violence prevalence depending on methods and approaches of data collection}

Studies show varying degrees of concordance in data prevalence of peer violence depending on the method and approach used in data collection. Generally there is a low $(\mathrm{r}=0.10)(\mathrm{Pa}-$ kaslahti \& Keltikangas-Järvinen, 2000) to moderate $(r=0.50)$ correlation between the prevalence of peer violence assessed by peer ratings and self-ratings (Ladd \& Kochenderfer-Ladd, 2002) whereby the correlation is higher when older students (adolescents) are tested and when the direct violent behavior (as opposed to indirect violence) is examined (Olweus, 2010). 
DRUŠ. ISTRAŽ. ZAGREB GOD. 23 (2014), BR. 2 STR. 259-281

VELKI, T., KUTEROVAC JAGODIĆ, G. DIFFERENT.. peer violence is lower in middle adolescence $(r=0.20$ for indirect violence to 0.30 for direct violence) than in early adolescence when it is around $\mathrm{r}=0.50$ for both indirect and direct violence (Pakaslahti \& Keltikangas-Järvinen, 2000). However, except for a few meta-analytic studies (Cook et al., 2010a; Knight et al., 2002), studies that take into account the different measurement approaches, when analyzing the correlation between various measures of peer violence, are rare. One such study was conducted by Pellegrini and Bartini (2000) on a sample of 367 secondary school students of adolescent age. The self-rating of peer violence (behavioral approach) was moderately correlated with peer nominations when the definitional approach was applied, $\mathrm{r}=0.47$, but weakly correlated with peer nominations when the behavioral approach was applied $\mathrm{r}=0.18$. In this research higher correlations were also obtained between peer and teacher ratings ( $r=0.28$ to 0.52 ) compared to the correlations between self-ratings and teacher ratings ( $r=0.24$ to 0.35 ). Also, in this study, the diary method with students recording their violent behavior (definitional approach) was used and a low correlation $(r=0.20)$ was found with self-ratings of violent behavior (behavioral approach), and a slightly higher correlation with teacher and peer ratings $(\mathrm{r}=0.24$ to 0.36$)$. An additional problem is the fact that the correlation between different measures of peer violence depends on the gender and age of the children. For example, the correlation between self-ratings and peer ratings of the frequency of peer violence was higher for direct violence and boys, and this correlation increases with age (Ladd \& Derfer-Ladd, 2002).

The aim of this study was to investigate the differences in the results of the prevalence of peer violence when using different measurement approaches (definitional and behavioral) and different data collecting methods (self-rating, peer rating, peer nomination, self-nomination). Because it is ethically and methodologically extremely difficult to use different methods and approaches on the same children, but in order to achieve this goal, data from two waves of data collection from a broader study that investigates the factors of peer violence were combined.

\section{METHOD}

\section{Participants}

Primary school pupils from two towns in Slavonia participated in the research. The first sample consisted of 325 participants, pupils from fifth to eighth class of primary school ( $50.2 \%$ girls), the average age being $\mathrm{M}=12.3$ years $(\mathrm{sd}=1.22$ ). About $10 \%$ $(\mathrm{N}=32)$ of the pupils from this sample did not participate in 
DRUŠ. ISTRAŽ. ZAGREB GOD. 23 (2014), BR. 2, STR. 259-28

VELKI, T., KUTEROVAC JAGODIĆ, G.: DIFFERENT...

\section{Instruments}

the research because they were absent from school during the research. In the second sample, there were 880 participants, pupils from fifth to eighth class of primary school (52\% girls) and the average age was of $\mathrm{M}=12.8$ years $(\mathrm{sd}=1.15)$. About $30 \%(\mathrm{~N}=401)$ of pupils from this sample did not participate in the research because they did not have their parents' permission to participate in the research.

\section{Self-rating of perpetrated and experienced} peer violence using the behavioral approach

For the self-rating of perpetrated and experienced peer violence based on the behavioral approach, the School peer violence questionnaire (Upitnik o nasilju među školskom djecom, Croatian acronym UNŠD; Velki, Kuterovac Jagodić, \& Vrdoljak, 2011) was used. This instrument measures the frequency of perpetrated and experienced peer violence and consists of 2 scales. The Peer violence scale measures the frequency of perpetrated peer violence in school and the Peer victimization scale measures the frequency of experienced peer violence in school. Both scales consist of 19 items. The Peer violence scale consists of two subscales: the Subscale of peer violence in school (13 items divided into the Subscale of verbal peer violence -6 items and the Subscale of physical peer violence -7 items) and the Subscale of cyber peer violence (6 items). The Peer victimization scale consists of two subscales: the Subscale of peer victimization in school (13 items divided into the Subscale of verbal peer victimization -6 items and the Subscale of physical peer victimization -7 items) and the Subscale of cyber peer victimization (6 items). Children mark the frequency of the described perpetrated/experienced type of peer violence on a 5-point scale (1 - "never", 2 - "rarely (few times per year)", 3 - "sometimes (once per month)", 4 - "often (few times per month)", and 5 - "always (almost every day)"). The result for each subscale is formed based on the average response of the corresponding items, and the theoretical span is between 1 and 5 . The internal consistency reliability for the Peer violence scale and its subscales ranges from 0.66 to 0.83 and for the Peer victimization scale and its subscales from 0.70 to 0.87 .

\section{Peer rating and self-rating of peer} violence frequency using the definitional approach

For the purpose of peer rating and self-rating of the frequency of peer violence based on the definitional approach, a sociometric technique was used. Pupils were given Olweus' definition of peer violence ("Some children or groups of children constantly and deliberately attack, harass or injure other children who cannot defend themselves. They are usually 
DRUŠ. ISTRAŽ. ZAGREB GOD. 23 (2014), BR. 2 STR. 259-281

VELKI, T., KUTEROVAC JAGODIĆ, G DIFFERENT.. doing it in a way to threaten them, mock them, teasing, gossiping, taking things from them, destroying their things, hitting them, pushing, excluding them from games or other activities, and saying nasty things about their family or relatives."). They were given a list of names and were supposed to rate each pupil in their class from that list in terms of the frequency of doing the described and similar behaviors on a Likert scale, where 1 means that a pupil never shows that or similar behavior, 2 means that a pupil sometimes shows that or similar behavior (few times per year) and 3 means that a pupil often shows that or similar behavior (few times per month). The pupils also needed to rate themselves on the same scale. A total result of peer violence was formed for each pupil based on the average responses from all the pupils who gave peer ratings.

\section{Peer nomination and self-nomination \\ of peer violence using the definitional approach}

The sociometric technique of peer nomination and self-nomination of peer violence based on the definitional approach was used to investigate who the children are who stand out in verbal, physical and cyber peer violence. The pupils were given the definition of three different types of peer violence and were asked to nominate the classmates from the name list of their class who behave in the described way more often than the other pupils in the class. It was possible for a pupil to nominate him/herself for the violent behavior. The definition of verbal peer violence included behaviors such as teasing, gossiping, mocking, saying nasty things, insulting or excluding pupils from games or other activities. The definition of physical peer violence depicted a person who punches, pushes, hurts, threatens, intentionally loses or destroys other children's things, robs someone else's money or touches other children's body in an uncomfortable way. Finally, the definition of cyber peer violence depicted a person who insults other children using the Internet (e.g. uses offensive nicknames, falsely represents him/herself, sends threatening or insulting messages via Facebook, chat, forum or blog). Total range of the scores for nomination and self-nomination for each pupil was from 0 (no nominations) to 3 (the pupil was nominated for all three types of peer violence by at least one person or by her/himself).

\section{Procedure}

The data were collected during regular classes in schools with the permission of an authorized institution and written parental and child's verbal consent after the authorities, parents and children were informed about the main goals and the purpose of the research, as well as about the procedure. The 
DRUŠ. ISTRAŽ. ZAGREB GOD. 23 (2014), BR. 2, STR. 259-28

VELKI, T., KUTEROVAC JAGODIĆ, G.: DIFFERENT... pupils were asked to guarantee confidentiality of information about the assessments of other children in the survey. The data were collected in groups, and their collection lasted about 45 minutes. In the first sample, the pupils first rated the peer violence among their classmates and themselves using Olweus' definition of peer violence (definitional approach). After that, they filled out the School peer violence questionnaire. The data collection was conducted by the school psychologists. In this sample, all the children were given parental consent for participation in the research. The pupils from the second sample rated peer violence first by means of the definitional approach and the methods of nomination and self-nomination based on the definitions of three different types of peer violence. After that, they also filled out the School peer violence questionnaire. The data were collected by one of the authors of the study, and in this sample, the rate of parental consent for children's participation was $69 \%$. Although all children in the class did not participate in the study, due to the nature of the method of peer nomination, the data about the perpetration of peer violence were collected for all the pupils in the classrooms. Namely, in order to preserve the social structure of a class, every child in the class could have been nominated irrespectively of whether he/she participated in the study or not. After the completion of the research, the pupils were offered to talk about peer violence and other problems with the school psychologists and researchers, and they received contact telephone numbers and e-mails for possible further questions.

\section{RESULTS}

Before comparing the obtained data on the prevalence of peer violence collected by different methods, it is important to explain the criteria that were used to categorize children as perpetrators. As for the behavior-based approach, or self-assessment by questionnaires, the criterion for the identification of a child as a perpetrator was that the pupil indicated on at least one item in the School peer violence questionnaire that she/he does the described violent behavior "always" ("almost every day") or "often" ("several times a month"). As for the definitional approach, in which peers assessed each classmate using Olweus' definition of violence, a pupil was identified as a perpetrator if the mean assessment of his/her classmates who participated in the study equaled 2.5 or more. Number 2 on the scale denoted "sometimes" ("several times a year") and number 3 denoted "often" ("several times a month"). When the method of self-rating by the definitional approach with Olweus' definition was used, a pupil was identified as a per- 
DRUŠ. ISTRAŽ. ZAGREB GOD. 23 (2014), BR. 2 STR. 259-281

VELKI, T., KUTEROVAC JAGODIĆ, G. DIFFERENT.. petrator if he/she indicated that he or she does the described violent behavior "often" ("several times a month"). By means of the method of self-nomination on the basis of the definitions of physical, verbal, and electronic violence, a pupil was identified as a perpetrator if he/she stated committing at least one of these three kinds of violence more often than other classmates. Finally, by means of the method of nomination on the basis of the definitions of physical, verbal and electronic violence, the pupil was considered a perpetrator if at least 50\% of classmates had nominated him/her as someone who commits the described violence more often than other pupils in the classroom.

\section{Preliminary analyses}

A comparison of the two samples did not show a statistically significant gender difference in the number of boys and girls ( $50.2 \%$ vs. $52 \%$ of girls, $z=0.6$, n.s.). However, although both samples consisted of 5th to 8th graders, the first sample was on average significantly younger than the second one $(\mathrm{M}=12.3$, $\mathrm{sd}=1.22$ vs. $\mathrm{M}=12.8, \mathrm{sd}=1.15, \mathrm{t}=6.41, \mathrm{df}=549,2, \mathrm{p}<0.001)$.

As already mentioned, the response rate in the second study was $69 \%$, and the predominant reason for students' refraining was the absence of parental consent. However, since the participating pupils could nominate all the children from the class no matter whether they participated in the study or not, the data on physical, verbal, and electronic violence was obtained even for those children who did not actively participate in the study. Therefore, it was possible to compare participating and non-participating pupils in different types of violent behavior towards peers. Although the plan was to collect data for all $\mathrm{N}=1275$ pupils, some data were missing since for several pupils their classmates did not give valid ratings, and for others the data about them were considered unreliable since they were based on ratings of less than $50 \%$ of the children from their class. Therefore, the degrees of freedom for the performed ANOVAs are less than theoretically assumed $(\mathrm{ss}=1074$ vs. 1275$)$. Statistically significant differences were obtained between participating and non-participating children for all three kinds of measures of peer violence except for electronic violence. The pupils who refrained from the research were assessed as generally more violent towards peers $(\mathrm{F}(1,1074)=8.18, \mathrm{p}<0.01)$, as well as more verbally $(\mathrm{F}(1,1074)=$ $10.22, p<0.01)$ and more physically violent $(F(1,1074)=8.09$, $\mathrm{p}<0.01)$ than those who participated in the study. That indicates that our second sample was biased, i.e. that it underestimated the prevalence of peer violence since it did not include children that are more verbally and physically aggressive. How- 
DRUŠ. ISTRAŽ. ZAGREB GOD. 23 (2014), BR. 2, STR. 259-28

VELKI, T., KUTEROVAC JAGODIĆ, G.: DIFFERENT... $\because$ TABLE

Prevalence of children engaged in different roles in peer violence obtained by self-ratings on the School peer violence questionnaire (behavioral approach) ever, due to the ethical considerations with regard to doing research with children, this kind of bias was inevitable since only children with parental consent were able to participate.

Since the School peer violence questionnaire was administered in both samples, it was possible to classify the children according to their role in peer violence: uninvolved, passive victims, provocative victims and perpetrators of violence. A pupil was identified as a perpetrator of violence if he/she indicated on at least one item of the subscale of committing peer violence that the described violence is performed "almost every day" or "several times a month". Similarly, a pupil was identified as a passive victim of violence if he/she indicated on at least one item of the subscale of experiencing peer violence that the described violence is experienced "almost every day" or "several times a month". Provocative victims were identified as those pupils who report that they both perform and experience a particular kind of violence "always" or "often". The uninvolved were all the children who indicated that they experience/commit a certain type of violence "never", "rarely", or "sometimes". The percentages of the pupils from the two samples involved in different roles in peer violence are shown in Table 1. Since the self-rating on the behavioral questionnaire of violence was the only common measure of peer violence used in both samples, the analysis provided support for their comparability. In both samples, we found a very similar percentage of children engaged in different roles in peer violence, and that fact also justified the comparison of the results on the prevalence of peer violence in the two samples yielded by other methods and approaches to measurement.

\begin{tabular}{lcc}
\hline Role in peer violence & First sample $(\%)$ & Second sample $(\%)$ \\
\hline Uninvolved & 52.0 & 52.7 \\
Victims & 30.9 & 29.4 \\
Provocative victims & 13.7 & 13.6 \\
Perpetrators & 3.1 & 4.2 \\
\hline
\end{tabular}

* t-test of proportions did not find statistically significant differences in the prevalence for any roles in peer violence between the two samples

A comparison of our results with the data on the prevalence of peer violence obtained on a representative national sample of school-aged children by Sušac, Rimac, and Ajduković (2012) further supported the fact that our samples were relatively representative. Namely, when studying 7 th grade children, those authors found $6.5 \%$ perpetrators, $17.6 \%$ passive victims and $7.7 \%$ provocative victims. In spite of the fact that our results were not obtained on representative samples, 
DRUŠ. ISTRAŽ. ZAGREB GOD. 23 (2014), BR. 2 STR. 259-281

VELKI, T., KUTEROVAC JAGODIĆ, G DIFFERENT..

(4) TABLE 2

Correlations among different approaches and methods of measurements of peer violence but rather on two convenience samples from two Croatian towns in the Slavonic region, a remarkable similarity of the data on the prevalence of committed violence ( 3 to $4 \%$ vs. $6.5 \%$ ) supports the possibility of generalization of our results obtained by other methods as well. The fact that Sušac, Rimac, and Ajduković (2012) obtained their results by a different questionnaire than ours, additionally advocates for both the representativeness of our samples, and for the construct validity of both self-rating instruments.

Table 2 shows the correlations among the self-ratings and peer-ratings of total peer violence within the two samples. The correlations obtained by different measures and approaches were generally positive and significant but low to medium in the range, and that corresponds to results of earlier studies (e.g. Olweus, 2010). For reasons of space economy and similarity, correlations for different kinds of violence were omitted from Table 2 .

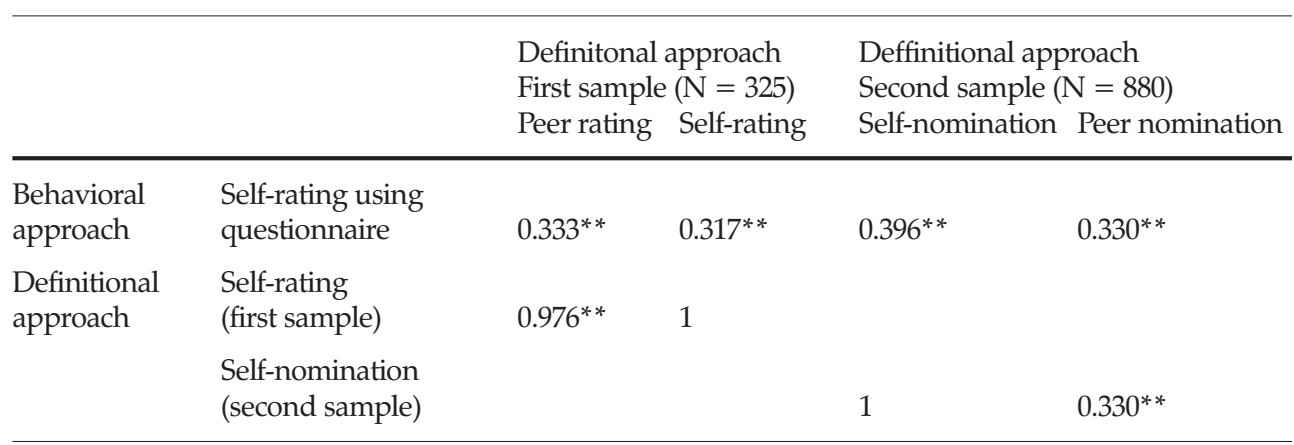

** $\mathrm{p}<0,01$

The highest correlation of $r=0.976$ was obtained when the same approach (definitional) and the same kind of measure (self-rating or peer-rating using Olweus' definition of peer violence) was used. A moderate association of methods was obtained within the definitional approach for the prevalence of total peer violence assessed by methods of nomination and self-nomination $(r=0.330)$. Almost identical correlations were obtained between self-ratings by means of the behavioral approach and the peer-ratings $(r=0.333)$, as well as peer-nominations $(r=0.330)$ in the definitional approach. The results are comparable to those attained in earlier studies (Ladd \& Kochenderfer-Ladd, 2002; Pakaslahti \& Keltikangas-Järvinen, $2000)$ that indicated low to medium positive correlations between self-ratings and peer ratings of violent behavior $(r=0.1-0.5)$. Although our results indicate low to moderate correlations between self-assessment methods used within two different approaches $(r=0.317-0.396)$, they are somewhat higher than correlations obtained in other studies (e.g. $r=0.20$; Pellegrini 
\& Bartini, 2000). Those correlations also speak in favor of the reliability of the data in the two samples and justify their mutual comparison, as well as their comparison with other data in this field.

\section{Prevalence of peer violence obtained by different methods}

The prevalence of peer violence in the two samples obtained by different approaches and methods of assessment are shown

(1) TABLE 3

Prevalence of peer violence found in the two samples using different approaches and methods of measurement of peer violence

\begin{tabular}{|c|c|c|c|c|c|c|c|}
\hline \multirow{3}{*}{$\frac{\text { Approach }}{\text { Method }}$} & & \multicolumn{3}{|c|}{ First sample $(\mathrm{N}=325)$} & \multicolumn{3}{|c|}{ Second sample $(\mathrm{N}=880)$} \\
\hline & & \multirow{2}{*}{$\begin{array}{l}\text { Behavioral } \\
\text { Self-rating } \\
\text { using } \\
\text { questionnaire } \\
\text { UNŠD }\end{array}$} & \multicolumn{2}{|c|}{ Definitional } & \multirow{2}{*}{$\begin{array}{l}\text { Behavioral } \\
\text { Self-rating } \\
\text { using } \\
\text { questionnaire } \\
\text { UNŠD }\end{array}$} & \multicolumn{2}{|l|}{ Definitional } \\
\hline & & & Self- & Peer & & Self- & Peer \\
\hline \multirow{4}{*}{$\begin{array}{l}\text { Type of peer } \\
\text { violence }(\%)\end{array}$} & Total & 17.8 & 57.9 & 58.8 & 17.6 & 35.3 & 17.8 \\
\hline & Verbal & 14.2 & - & - & 12 & 33.2 & 17.5 \\
\hline & Physical & 9.2 & - & - & 9.7 & 8.9 & 5.7 \\
\hline & Cyber & 1.2 & - & - & 1.6 & 4.0 & 0.6 \\
\hline
\end{tabular}

For all methods higher prevalence of peer violence was found for boys; t-test of proportion did not show statistically significant differences in prevalence for any type of peer violence between the two samples; UNŠD - School peer violence questionnaire.

\section{DISCUSSION}

One of the distinctive characteristics of peer violence is that it is a behavior that is repeated regularly, but there is no consensus in the studies, nor in the literature, on the critical frequency of some behavior that can be considered as repeated violence (Swearer et al., 2010). Two cut-off criteria are mostly used in the studies: a violent behavior that is committed once a month is usually the lower criterion, while the higher one is the frequency of several times a month or more often (Bovaird, 2010; Cook et al., 2010a). In this study, an attempt was made to even out the criteria that were used for the identification of the perpetrators of peer violence identified by different methods and approaches as much as possible in order to get valid and reliable prevalence data. For the self-nomination in the behavioral approach, the criterion was the frequency of committing a violent behavior several times a month or more, while for the peer-ratings and self-ratings in the definitional approach the criteria were behaviors repeat- 
DRUŠ. ISTRAŽ. ZAGREB GOD. 23 (2014), BR. 2 STR. 259-281

VELKI, T., KUTEROVAC JAGODIĆ, G. DIFFERENT.. edly performed several times a month. For the peer nomination method, the criterion was the nomination by peers as someone who is more often violent than the other children in the class by $50 \%$ or more classmates, and for self-nomination, the criterion was the performance of the violent behavior more often than the other children. Although the criteria were not completely uniform, they were similar to those usually used in the studies of peer violence.

\section{Definitional vs. behavioral approach}

The results in Table 3 show that the use of the definitional approach in the assessment of peer violence enabled the identification of more perpetrators (17.8\% to $58.8 \%$ ) than the use of the behavioral approach $(17.6 \%$ and $17.8 \%)$. The number of the identified perpetrators was particularly high when Olweus' definition of peer violence was used, and in that case there was no difference whether the method of peer-rating $(58.8 \%)$ or self-rating of peer violence was used $(57.9 \%)$. Within the definitional approach, the higher prevalence of peer violence was found with the use of Olweus' omnibus definition of peer violence (57.9\% and 58.8\%) than with the use of separate definitions for different types of violence and they were aggregated in the total result (17.8\% and 35.3\%). It should be noted that the cut off criteria for both of the described definitional approaches (omnibus definition, separate definitions) were the same (frequency of violence several times a month), while the criteria for the self-nomination and nomination were somewhat different (for self-nomination "performing the described behavior more often than the other kids" vs. for peer nomination that $50 \%$ or more classmates identified that a child commits violence more often than others). The aforementioned differences in the cut-off criteria could be the reason for getting more similar data on the prevalence when the same criterion was used (in the definitional approach with Olweus' definition and behavioral approach), than when different criteria were used for different methods within the same approach (nomination and self-nomination in the definitional approach). Our results correspond with those found in previous studies. In the extensive meta-analysis of 82 studies, Cook and colleagues (2010b) found that researchers who had used the definitional approach identified higher numbers of perpetrators than those who had used the behavioral approach. Not unexpectedly, they found the highest prevalence in the studies that used Olweus' definition of peer violence (around $58 \%$ ). That definition is broad and all-embracing since it describes different kinds of peer violence, i.e. physical, verbal, relational and others, so that many children could recognize 
DRUŠ. ISTRAŽ. ZAGREB GOD. 23 (2014), BR. 2, STR. 259-28

VELKI, T., KUTEROVAC JAGODIĆ, G.: DIFFERENT... themselves and their peers in these behaviors. It is also possible that children may have difficulties with identifying children who satisfy some or all of the criteria described in that long and complex definition. It may be that children, confronted with such a complex task, conclude that even someone who does at least one of the described behaviors is a bully and, therefore, the number of identified perpetrators is higher than when a more analytical behavioral approach, that describes simple and separate behaviors, is used. The same reason probably explains why the data show less prevalence when narrower definitions for particular kinds of peer violence, such as physical or verbal, are used. It is easier for the participants, particularly younger children, to focus and identify perpetrators when separate kinds of violence are described, than when they include several behaviors and someone does one thing and not the rest. Shorter and clearer definitions allow a more accurate assessment of violent behaviors. Our results point to the fact that the differences between the samples and methods are the most prominent when it comes to the assessment of cumulative or total peer violence (from $17.6 \%$ to $58.8 \%$ ). However, when it comes to the assessment of particular kinds of violent behavior, the results on prevalence are more consistent, so for verbal violence they vary from $14.2 \%$ to $33.2 \%$, for physical from $5.7 \%$ to $9.7 \%$, and for electronic violence from $0.6 \%$ to $4 \%$.

\section{Self-rating vs. peer-rating methods}

The comparison of prevalence data according to the source of information indicates that, when omnibus definition and rating scales were used, there were no significant differences in the identification of peer violence prevalence among the participants (58.8\% and 57.9\%). Such a result is expected since both methods used the same criteria for the identification of perpetrators (the children assessed themselves or other children who perform the described behavior several times a month). However, when more focused definitions for specific types of violent behavior were used, and the data were aggregated later, significant differences between the participants occurred. The prevalence was twice as high for total violence assessed by self-nomination compared to peer-nomination $(35.3 \%$ vs. $17.8 \%)$. However, the cut-off criteria in these assessments were not the same (nomination of $50 \%$ or more of schoolmates as someone who behaves violently more often than others vs. self-nomination of the child itself that he/she behaves violently more often than others). Our results correspond to the results from a meta-analysis of Cook et al. (2010a) who found that peer nomination resulted in lower 
DRUŠ. ISTRAŽ. ZAGREB GOD. 23 (2014), BR. 2 STR. 259-281

VELKI, T., KUTEROVAC JAGODIĆ, G. DIFFERENT.. prevalence than self-nominations and teacher-nominations. There are several possible explanations for such findings. It may be that the pupils are reluctant to identify classmates as violent because they fear of their retaliation or accusations for snitching, and, therefore, the numbers are underreported. In addition, adolescents may consider some violent acts as normative, and as those that are done as a joke or play, and do not report those who engage in them. However, when it comes to self-nominations children are more prone to assess themselves as violent, maybe because of the social pressure to be sincere or because they simply have more insight in their own behaviors and the intentions behind them. Such information, however, is not visible or readily accessible to their peers. The data for electronic violence, as the most covert type of peer violence, support the latter explanation since such behavior is almost seven times more frequent according to the self-nominations than according to peer-nominations ( $4 \%$ vs. $0.6 \%$ ). The data for readily visible physical violence, however, as assessed by different participants are more similar (for self-rating and self-nomination around $9 \%$ and for peer-nomination $5.7 \%$ ). Since some forms of violence, such as verbal, are acceptable and even desirable during adolescence because they indicate power and courage, children are more ready to report them: our results show a two to three times higher prevalence of verbal violence when the methods of self-nomination and self-rating were used than when the method of peer-nomination was used $(33.2 \%$ vs. $12 \%)$. Moreover, the detected prevalence of peer violence, both in our research and other studies, was the highest for verbal violence, followed by physical and electronic violence, irrespective of the method and approach used (Espelage, Mebane, \& Swearer, 2004; Olweus, 2010; Wang, Iannotti, \& Nansel, 2009). Coming into adolescence, children, particularly boys, become more tolerant toward expressions of violence. The violence becomes a mechanism for the achievement of domination and popularity (Bukowski, Sippola, \& Newcomb, 2000; LaFontana \& Cillessen, 2002). In addition, verbal violence is often unsanctioned by both peers and teachers, particularly among adolescents in upper classes who use them to establish leading positions in peer groups. Physical violence, on the other hand, confronts with judgments from both peers and teachers, and is usually more seriously sanctioned. This kind of violence is not considered normative, it and its consequences are easily observed, so it is not a surprise that it both occurs less often and is less reported. The observed prevalence for electronic violence is the lowest since that kind of behavior is most often anonymous, so the children have a problem assessing if one of their peers has committed it. On the other hand, they can give 
DRUŠ. ISTRAŽ. ZAGREB GOD. 23 (2014), BR. 2, STR. 259-28

VELKI, T., KUTEROVAC JAGODIĆ, G.: DIFFERENT... more accurate ratings of their own violence on the internet or through mobile phones and, therefore, the prevalence is higher. However, the different comparison of the data, leads us to the conclusion that adolescents are reliable informants and raters of their peers' violent behaviors. Namely, within the definitional approach in the second sample, self-ratings and peer-nominations resulted in a very similar prevalence of total peer violence of around 18\%, and are also similar to self-ratings when the behavioral approach was used in the first sample. Such a finding is very important since it points out that the data on the prevalence of total violence were insensitive to the differences in approaches, methods, and even in cut-off criteria used. The prevalence yielded by self-ratings and peer-ratings corresponded in the omnibus definitional approach as well (58\%), when the same criterion of several times a month was used. Similar results were found earlier (e.g. Cornell \& Bandyopadhyay, 2010), and are explained by the direct involvement of peers, yet in different roles, in the dynamics of peer violence within the group such as the class or the school. Peers are those that, besides the affected adolescent, are the most informed about frequency of peer violence. That is particularly true for direct forms of violence, such as verbal or physical, in which peers are either perpetrators or uninvolved witnesses. Adolescents in higher elementary school grades are particularly reliable informants and raters since they spend more time with peers, better understand social relations, and also better differentiate peer violence from other kinds of conflicts.

\section{Alternative explanations and limitations of the study}

With the presumption, supported by the preliminary data analysis, that the two samples were eligible for comparison, the study showed that data on the prevalence of peer violence are related to the approach and the methods of assessment. The use of the definitional approach resulted in data on a higher prevalence of peer violence than when the behavioral approach was used, and those findings correspond to some earlier studies on peer violence (Cook et al., 2010a). The method that resulted in the highest prevalence was peer-rating, while peer nomination resulted in the lowest incidence. The latter conclusion finds has support in some earlier studies (e.g. Knight et al., 2002).

However, some limitations of this study may be a source of precaution and the possibility of alternative explanations of the findings. Namely, the data that were compared were taken from two different studies, and not all the approaches and methods were used with the same participants. If that were the case, then the conclusion about the correlation between the method/approach of assessment and the preva- 
DRUŠ. ISTRAŽ. ZAGREB GOD. 23 (2014), BR. 2 STR. 259-281

VELKI, T., KUTEROVAC JAGODIĆ, G DIFFERENT..

\section{CONCLUSION}

lence would be more reliable. However, such a design would be too demanding for the participants and would bring other problems such as repeated measurement of the same issue several times. Furthermore, the data on peer prevalence were obtained on convenience samples and, therefore, the possibility for conclusions on the prevalence of peer violence in our country is limited. Also, since the data collection in the studies was not anonymous, that could have influenced the children's sincerity to report peer violence. A further problem is that because of that reason, the data could be skewed in at least two ways. Some children could have underreported their violent behavior because of the fear of being sanctioned for it, while others maybe did not report their violent peer because of the fear of retaliation if perpetrators found out about it. The lack of anonymity was probably the reason why a significant number of parents (around 30\%) refused to give their consent for the children's participation in the second study. Our analysis showed that those children were on average more violent towards peers than their classmates who participated in the study. Finally, an aspect of this research that ensured scientifically important data about biases in our samples was ethically sensitive. Namely, in the method of nomination the children were able to nominate all the children from their classes, even if they did not participate in the study, and the participating children also rated all the children from their classrooms. The question is whether it is correct to ask about children who did not get the consent for participation and to use those data, but on the other hand, removing non-participating children from the possible pool for nomination and rating would make the collected data invalid and threaten their validity. Although there was no reasonable doubt of potential or real harm for non-participating children for whom we got data on peer violence, the question remains whether scientific benefit justifies the use of data collected that way. Future research should consider some of the mentioned disadvantages and conduct studies with representative national samples to increase the outside validity, use different approaches and methods for assessment of peer violence on the same participants in order to increase inside validity, and also make an effort to unify cut-off criteria for the significant frequency of peer violence.

Despite the described limitations, this study contributes to the methodological aspects of research on peer violence. The results showed the importance of a careful choice of approaches and methods of data collection about peer violence, since different approaches, different methods, and even different combinations of approaches and methods may result in re- 
DRUŠ. ISTRAŽ. ZAGREB GOD. 23 (2014), BR. 2, STR. 259-28

VELKI, T., KUTEROVAC JAGODIĆ, G.: DIFFERENT...

\section{REFERENCES}

markably different data on peer violence. The results point to the complexity of research of this troubling social issue, and stress the importance of bearing in mind how the data about prevalence is collected, and which cut-off criteria for the frequency of violent behavior should be used if the data from different studies are to be compared.

Brunstein Klomek, A., Sourander, A., Kumpulainen, K., Piha, J., Tamminen, T., Moilanen, I., Almqvist, F., \& Goud, M. S. (2008). Childhood bullying as a risk for later depression and suicidal ideation among Finnish males. Journal of Affective Disorders, 109(1-2), 47-55. doi:10. 1016/j.jad.2007.12.226

Bukowski, W. M., Sippola, L. A., \& Newcomb, A. F. (2000). Variations in patterns of attraction to same- and other- sex peers during early adolescence. Developmental Psychology, 36(2), 147-154. doi:10.1037/00121649.36.2.147

Buljan Flander, G., Durman Marijanović, Z., \& Ćorić Špoljar, R. (2007). Pojava nasilja među djecom s obzirom na spol, dob i prihvaćenost/odbačenost $\mathrm{u}$ školi [Bullying in Croatian schools with regard to gender, age and acceptance/rejection in school]. Društvena istraživanja, 16(1-2), 157-174.

Colvin, G., Tobin, R., Beard, K., Hagan, S., \& Sprague, J. (1998). The school bully: Assessing the problem, developing interventions, and future research directions. Journal of Behavioral Education, 8(3), 293-319. doi:10.1023/A:1022819213727

Cook, C. R., Williams, K. R., Guerra, N. G., \& Kim, T. E. (2010a). Variability in the prevalence of bullying and victimization: A cross-national and methodological analysis. In S. R. Jimerson, S. M. Swearer, \& D. L. Espelage (Eds.), Handbook of bullying in schools: An international perspective (pp. 347-362). New York: Taylor \& Francis Group.

Cook, C. R., Williams, K. R., Guerra, N. G., Kim, T. E., \& Sadek, S. (2010b). Predictors of childhood bullying and victimization in childhood and adolescence: A meta-analytic investigation. School Psychology Quarterly, 25(2), 65-83. doi:10.1037/a0020149

Cornell, D. G., \& Bandyopadhyay, S. (2010). The assessment of bullying. In S. R. Jimerson, S. M. Swearer, \& D. L. Espelage (Eds.), Handbook of bullying in schools: An international perspective (pp. 265-276). New York: Taylor \& Francis Group.

Due, P., Holstein, B. E., Lynch, J., Diderichsen, F., Gabhain, S. N., Scheidt, P., \& Currie, C. (2005). Bullying and symptoms among school-aged children: International comparative cross sectional study in 28 countries. European Journal of Public Health, 15(2), 128-132. doi:10.1093/ eurpub/cki105

Espelage, D. L., Mebane, S. E., \& Swearer, S. M. (2004). Gender differences in bullying: Moving beyond mean level differences. In D. L. Espelage, \& S. M. Swearer (Eds.), Bullying in American schools: A social-ecological perspective on prevention and intervention (pp. 15-35). Mahwah, NJ: Erlbaum. 
DRUŠ. ISTRAŽ. ZAGREB GOD. 23 (2014), BR. 2, STR. 259-281

VELKI, T., KUTEROVAC JAGODIĆ, G. DIFFERENT...
Farrington, D. P. (1993). Understanding and preventing bullying. In M. Tonry, \& N. Morris (Eds.), Crime and justice (pp. 381-458). Chicago: University of Chicago Press.

Fekkes, M., Pijpers, F. I. M., \& Verloove-Vanhorick, S. P. (2004). Bullying behaviour and associations with psychosomatic complaints and depression in victims. Journal of Pediatrics, 144(1), 17-22. doi:10. 1016/j.jpeds.2003.09.025

Hugh-Jones, S., \& Smith, K. (1999). Self-reports of short- and long-term effects of bullying on children who stammer. British Journal of Educational Psychology, 69(2), 141-158. doi:10.1348/000709999157626

Knight, G. P., Guthrie, I. K., Page, M. C., \& Fabes, R. A. (2002). Emotional arousal and gender differences in aggression: A meta-analysis. Aggressive Behavior, 28(5), 266-393. doi:10.1002/ab.80011

Kumpulainen, K. (2008). Psychiatric conditions associated with bullying. International Journal of Adolescent Medicine and Health, 20 (2), 121-132. doi:10.1515/IJAMH.2008.20.2.121

Ladd, G. W., \& Kochenderfer-Ladd, B. (2002). Identifying victims of peer aggression from early to middle childhood: Analysis of cross-informant data from concordance, estimation of relational adjustment, prevalence of victimization, and characteristics of identified victims. Psychological Assessment, 14(1), 74-96. doi:10.1037/1040-3590.14.1.74

LaFontana, K., \& Cillessen, A. H. N. (2002). Children's perceptions of popular and unpopular peers: A multimethod assessment. Developmental Psychology, 38(5), 635-647. doi:10.1037/0012-1649.38.5.635

Olweus, D. (1996). The Revised Olweus Bully/Victim Questionnaire. Mimeo. Bergen, Norway: Research Centre for Health Promotion, University of Bergen.

Olweus, D. (1998). Nasilje među djecom u školi: što znamo $i$ što možemo učiniti [Bullying among children in school: What we know and what we can do]. Zagreb: Školska knjiga.

Olweus, D. (2010). Understanding and researching bullying: Some critical issues. In S. R. Jimerson, S. M. Swearer, \& D. L. Espelage (Eds.), Handbook of bullying in schools: An international perspective (pp. 9-33). New York: Taylor \& Francis Group.

Pakaslahti, L., \& Keltikangas-Jarvinen, L. (2000). Comparison of peer, teacher and self-assessments on adolescent direct and indirect aggression. Educational Psychology, 20(2), 177-190. doi:10.1080/713663710 Pellegrini, A. D., \& Bartini, M. (2000). An empirical comparison of methods of sampling aggression and victimization in school settings. Journal of Educational Psychology, 92(2), 360-366. doi:10.1037/ 0022-0663.92.2.360

Perry, D. G., Kusel, S. J., \& Perry, L. C. (1988). Victims of peer aggression. Developmental Psychology, 24(6), 807-814. doi:10.1037/0012-1649. 24.6.807

Profaca, B., Puhovski, S., \& Luca Mrđen, J. (2006). Neke karakteristike pasivnih i provokativnih žrtava nasilja među djecom [Some characteristics of passive and provocative victims of bullying]. Društvena istraživanja, 15(3), 575-590. 
DRUŠ. ISTRAŽ. ZAGREB GOD. 23 (2014), BR. 2, STR. 259-28

VELKI, T., KUTEROVAC JAGODIĆ, G.: DIFFERENT...
Rajhvajn Bulat, L., \& Ajduković, M. (2012). Obiteljske i psihosocijalne odrednice vršnjačkog nasilja među mladima [Family and psychosocial determinants of youth peer violence]. Psihologijske teme, 21(1), 167-194.

Rigby, K. (2003). Consequences of bullying in schools. Canadian Journal of Psychiatry, 48(9), 583-590.

Stassen Berger, K. (2007). Update on bullying at school: Science forgotten? Developmental Review, 27(1), 90-126. doi:10.1016/j.dr.2006.08.002

Sušac, N., Rimac, I., \& Ajduković, M. (2012). Epidemiološko istraživanje nasilja među djecom [Epidemiological research of peer violence among children]. Paper presented at the National Conference "The prevalence of violence against children in the family and among peers", 22-23 March 2012, Zagreb, Croatia.

Swearer, S. M., Siebecker, A. B., Johnsen-Frerichs, L. A, \& Wang, C. (2010). Assessment of bullying/victimization. In S. R. Jimerson, S. M. Swearer, \& D. L. Espelage (Eds.), Handbook of bullying in schools: An international perspective (pp. 305-327). New York: Taylor \& Francis Group.

Velki, T., \& Vrdoljak, G. (2011). Validacija Upitnika o nasilju među školskom djecom (UNŠD) [Validation of the Questionnaire on peer violence among school children]. Preliminary report from the International Scientific Psychology Meeting 20th Ramiro and Zoran Bujas' Days, 7-9 April 2011, Zagreb, Croatia.

Wang, J., Iannotti, R. J., \& Nansel, T. R. (2009). School bullying among adolescents in the United States: Physical, verbal, relational, and cyber. Journal of Adolescent Health, 45(4), 368-375. doi:10.1016/j.jadohealth. 2009.03.021

Williams, K. R., \& Guerra, N. G. (2007). Prevalence and predictors of internet bullying. Journal of Adolescent Health, 41(6), S14-S21. doi:10. 1016/j.jadohealth.2007.08.018

\section{Različiti pristupi mjerenju kao izvori razlika u podacima o raširenosti nasilničkoga ponašanja među djecom}

Tena VELKI

Učiteljski fakultet, Osijek

Gordana KUTEROVAC JAGODIĆ

Filozofski fakultet, Zagreb

Cilj istraživanja bio je usporediti podatke o raširenosti vršnjačkoga nasilničkog ponašanja kada se rabe različiti pristupi (definicijski i ponašajni) i različite metode prikupljanja podataka (samoprocjena, procjena vršnjaka, nominacija vršnjaka, samonominacija). U radu su uspoređivani podaci prikupljeni na dva nezavisna uzorka osnovnoškolske djece iz dva slavonska grada. Raširenost vršnjačkoga nasilja u oba je uzorka mjerena ponašajnim pristupom primjenom metode samoprocjene. Učenici iz 
DRUŠ. ISTRAŽ. ZAGREB GOD. 23 (2014), BR. 2 STR. 259-281

VELKI, T., KUTEROVAC JAGODIĆ, G

DIFFERENT.. prvog uzorka procijenili su još vlastita i nasilnička ponašanja vršnjaka iz razreda koristeći definiciijski pristup. Učenici iz drugog uzorka još su na temeliu zadane definicije nasilničkoga ponašanja metodom nominacije i samonominacije identificirali nasilna ponašanja kod sebe i/ili suučenika. Rezultati indiciraju veće stope prevalencije nasilničkoga ponašanja kada se ona utvrđuje definicijskim nego ponašajnim pristupom, $i$ to neovisno o metodi procjene. Samoprocjene na temelju ponašajnoga pristupa i nominacije vršnjaka na temelju definicijskoga pristupa pokazale su podjednaku prevalenciju nasilničkoga ponašanja, dok je nešto veća prevalencija dobivena kod samonominacija uz pomoć definicijskoga pristupa. Zaključeno je kako je u ispitivanju raširenosti vršnjačkoga nasilja nužno rabiti multimetodski pristup.

Ključne riječi: prevalencija, nasilničko ponašanje među djecom, ponašajni pristup, definicijski pristup, nominacija, procjena 